\title{
Short communication \\ Industrial effluent treatments using heavy-metal removing bacterial bioflocculants
}

\author{
J Lin* and C Harichund \\ School of Biochemistry, Genetics, and Microbiology, University of KwaZulu-Natal (Westville), \\ Private Bag X54001, Durban, South Africa
}

\begin{abstract}
Bioflocculants produced by Herbaspirillium sp. CH7, Paenibacillus sp. CH11, Bacillus sp. CH15 and a Halomonas sp. were preliminarily evaluated as flocculating agents in the treatment of industrial wastewater effluents. Industrial (1 local chemical-industry and 2 textile-industry: Biavin 109 -medium blue dye and Whale dye) effluent $(9 \mathrm{~m} \ell)$ containing various heavy metals was vortexed with $1 \mathrm{~m} \ell$ of bioflocculant in a $25 \mathrm{~m} \ell$ test tube. One $\mathrm{m} \ell$ of water (Millipore Elix purification system, 17 mega $\Omega$ ) was substituted for the bioflocculant in the control. After $5 \mathrm{~min}$, the heavy metal concentrations, the microbial population and the turbidity of the top layer of the industrial effluent were determined using ICP-OES, spread-plate technique and a turbidity meter respectively. The flocculating activity was calculated based on absorbance at a wavelength of $550 \mathrm{~nm}$. Bioflocculants produced in this study were capable of removing several heavy metals from industrial effluents simultaneously and effectively. This was significant $(p<0.05)$ when applied to Biavin medium blue dye, with $95 \%$ of $\mathrm{Cr}^{2+}$ and $94 \%$ of $\mathrm{Ni}^{2+}$ removed by the presence of bioflocculants. Bioflocculants also removed almost all of the bacteria and reduced $50-80 \%$ of the turbidity of the chemical effluent sample, simultaneously. Bacterial bioflocculants may provide an alternative means of treating industrial wastewater resulting in environmental and economical benefits. However, our findings suggest that the treatment of industrial effluents using bioflocculants might be effluent-dependent. In order to explore the potential of bioflocculants in the treatment of industrial effluents, a preliminary study to determine the optimal conditions is crucial.
\end{abstract}

Keywords: bioflocculant; heavy metals; industrial effluent; flocculating activity, bacterial removal

\section{Introduction}

Heavy metal pollution is a significant environmental problem. Anthropogenic activities, such as mining operations and the discharge of industrial wastes, have resulted in the accumulation of metals in the environment and the food chain, bringing about serious environmental pollution, threatening ecosystems and human health (Chisti, 2004). For example, Kozul et al. (2009) demonstrated that chronic exposure to arsenic significantly compromises the immune response to influenza. To ensure environmental pollution control, removal of toxic heavy metals from industrial wastewaters is essential (Guangyu and Thiruvenkatachari, 2003).

Biological materials or dead bacterial cells (Zheng et al., 2008), algae (El-Sheekh et al., 2005), protozoans (Rehman et al., 2008), yeasts, fungi (Guangyu and Thiruvenkatachari, 2003) and plants (Heredia and Martin, 2009) have been shown to play significant roles in heavy metal removal and recovery. Amongst bioremediants, bioflocculants have gained increasing attention since they are environmentally-friendly, biodegradable and non-toxic (Shih et al., 2001). Bioflocculants contain various organic groups, such as uronic acids (containing a carbonyl and a carboxylic acid function) (Aguilera et al., 2008, Lu et al., 2005; Wu and Ye, 2007), glutamic and aspartic acid in the protein component (Dignac et al., 1998) or galacturonic

* To whom all correspondence should be addressed.

일 +2731-2607407; fax: +2731-2607809; e-mail: linj@ukzn.ac.za

Received 21 December 2009; accepted in revised form 8 March 2011. acid and glucuronic acid in the polysaccharide component (Bender et al., 1994), which are responsible for binding metals.

More researchers are now focusing their attention on industrial wastewater treatments (El.-Sheekh, 2005; Gao et al., 2009; Liu et al., 2009; Lu et al., 2005; Wang et al., 2007) and on drinking water treatment (Li et al., 2009) using microbial bioflocculants. The use of bioflocculants in wastewater treatment seems to be an economical alternative to physical and chemical means (Vijayalakshmi and Raichur, 2003). Unlike mono-functional ion exchange resins and other physicochemical methods, bioflocculants are capable of removing inorganic/ organic particles through their flocculating activity. In addition, bioflocculants can remove microorganisms and heavy metals (Kurane et al., 1994; Gao et al., 2009). Several bioflocculantproducing microorganisms have been isolated from an industrial effluent. The current study investigated the efficiency of bioflocculant activity in removing suspended solids, heavy metals and bacteria, and in reducing the turbidity of 3 different types of industrial wastewater effluents.

\section{Materials and methods}

\section{Production of bioflocculants}

Four different bioflocculant-producing microorganisms with heavy metal removing ability, namely, Herbaspirillium $\mathrm{sp}$. CH7, Paenibacillus sp. CH11 and Bacillus sp. CH15, isolated from a local industrial filtered sludge effluent sample (Lin and Harichund, unpubl. data) and a Halomonas sp. obtained from the Department of Microbiology, University of KwaZulu-Natal Westville campus, were used in this study. The above isolate 
was cultivated in a $250 \mathrm{~m} \ell$ Erlenmeyer flask containing $30 \mathrm{~m} \ell$ YMPG media $(0.3 \%$ yeast extract, $0.3 \%$ malt extract, $0.5 \%$ polypeptone, $1 \%$ glucose and $2 \%$ agar at $\mathrm{pH} 7$ ) at $28^{\circ} \mathrm{C}, 220 \mathrm{r} / \mathrm{min}$ for $20 \mathrm{~h}$ (Nakata and Kurane, 1999). A $0.7 \mathrm{~m} \ell$ portion of the cultivated bacterial strains was inoculated into $70 \mathrm{~m} \ell$ of production medium $(0.5 \%$ yeast extract, $0.5 \%$ polypeptone, $2 \%$ ethanol, $1 \%$ glycerol, $0.05 \% \mathrm{~K}_{2} \mathrm{HPO}_{4}, 0.05 \% \mathrm{MgSO}_{4} 7 \mathrm{H}_{2} \mathrm{O}, 0.2 \% \mathrm{NaCl}$, and $0.2 \% \mathrm{CaCO}_{3}$ ), under the above conditions, for $72 \mathrm{~h}$ (Nakata and Kurane., 1999). The bioflocculant was recovered from the supernatant after centrifugation $(4000 \mathrm{xg})$ for $15 \mathrm{~min}$ and precipitated overnight by adding 2 volumes of ethanol at $4^{\circ} \mathrm{C}$. The pellets were centrifuged at $4000 \mathrm{xg}$ for $15 \mathrm{~min}$ and dried in a desiccator containing anhydrous cobalt chloride at room temperature under reduced pressure. Productivity of the biofloccualants was expressed in terms of the dry weight after ethanol precipitation of the culture supernatant (Kurane et al., 1994).

\section{Flocculating activity, percentage of heavy-metal removal and heterotrophic counts of industrial effluent samples treated with bacterial bioflocculants}

The potential of bacterial bioflocculants for removing heavy metals, organic/inorganic contents and bacterial populations of industrial effluent samples was assessed. A local chemical-industry and 2 textile-industry effluent samples (Biavin 109-medium blue dye and Whale dye) containing various heavy metals were used in the following experiments. The protocol for wastewater treatments using bioflocculants followed the modified method of Nakata and Kurane (1999) and Gao et al. (2009). Bacterial bioflocculant $(1 \mathrm{~m} \ell$ at $1000 \mathrm{mg} / \ell)$ was mixed with $9 \mathrm{~m} \ell$ of industrial effluent sample. The mixture was vortexed for $30 \mathrm{~s}$ and rested for $5 \mathrm{~min}$. The upper layer of the solution $(3 \mathrm{~m} \ell)$ was then removed for further analyses. Flocculating activity was calculated based on $\mathrm{OD}_{550 \mathrm{~nm}}$, as described by Kurane et al. (1994). The heavy metal concentrations were also measured using ICP-OES. Heterotrophic plate counts of the effluent samples were determined using the spread-plate technique. Aliquots $(0.1 \mathrm{~m} \ell)$ of serially diluted effluent samples (pre- or post-bioflocculant treatment) were transferred onto nutrient agar and allowed to grow at $37^{\circ} \mathrm{C}$ for $24-48 \mathrm{~h}$. One $\mathrm{m} \ell$ of water (Millipore Elix purification system, 17 mega $\Omega$ ) was substituted for the bioflocculant in the control in all experiments.

\section{Statistical analysis}

All experiments were performed in triplicate and the results were expressed as the means \pm SD. Student $t$-tests were used to examine the statistically significant differences (SPSS version 15) for heavy-metal removal percentage, bioflocculating activity and turbidity reduction when applied to different industrial effluents using different bioflocculants. A significance level of $p<0.05$ was used. Correlations between the flocculating activities, and turbidity reductions of the effluents and heavy-metal removal efficiency of bioflocculants in the presence of various metals, were determined using Pearson correlation coefficient (SPSS Version 15).

\section{Results}

Analysis of 1 chemical- and 2 textile-industry effluent samples revealed the presence of various heavy metals (Table 1). High concentrations of $\mathrm{As}^{2+}(284 \mathrm{mg} / \ell)$ and $\mathrm{Zn}^{2+}(252 \mathrm{mg} / \ell)$ were

\begin{tabular}{|c|c|c|c|c|c|c|c|c|c|c|c|}
\hline \multicolumn{12}{|c|}{\begin{tabular}{|l} 
Percentage of hea \\
\end{tabular}} \\
\hline \multicolumn{12}{|c|}{ Chemical-industry effluent } \\
\hline Heavy metal $(\mathrm{mg} / \ell)^{\mathrm{c}}$ & $\begin{array}{l}\mathbf{A s}^{3+} \\
284 \\
\end{array}$ & $\begin{array}{c}\mathbf{C u}^{2+} \\
2.0 \\
\end{array}$ & $\begin{array}{c}\mathbf{P b}^{2+} \\
1.6\end{array}$ & $\begin{array}{c}\mathbf{M n}^{2+} \\
10.2 \\
\end{array}$ & $\begin{array}{c}\mathbf{N i}^{2+} \\
0.1\end{array}$ & $\begin{array}{c}\mathbf{A l}^{3+} \\
0.2\end{array}$ & $\begin{array}{c}\mathbf{Z n}^{2+} \\
252 \\
\end{array}$ & $\begin{array}{l}\mathbf{C r}^{2+} \\
0.93\end{array}$ & $\begin{array}{c}\mathbf{C d}^{2+} \\
0.1\end{array}$ & $\begin{array}{l}\mathbf{F e}^{2+} \\
0.94\end{array}$ & $\begin{array}{c}\mathbf{H g}^{2+} \\
0.6\end{array}$ \\
\hline Bioflocculant & \multicolumn{11}{|c|}{ Heavy metal removal (\%) } \\
\hline Herbaspirillium sp. & 26.6 & $\mathbf{0 . 0 0}$ & 72.9 & 31.4 & 0.00 & 0.00 & 39.5 & $\mathbf{0 . 0 3}$ & 0.00 & 1.30 & 33.3 \\
\hline Paenibacillus sp. & 21.7 & $\mathbf{0 . 0 0}$ & 75.0 & 27.0 & $\mathbf{0 . 0 0}$ & 0.00 & 33.4 & $\mathbf{0 . 1 0}$ & 0.00 & 1.30 & 27.8 \\
\hline Bacillus sp. ${ }^{\mathbf{a}}$ & 20.8 & $\mathbf{0 . 0 0}$ & 66.7 & 25.8 & 0.00 & 0.00 & 31.9 & 0.10 & 0.00 & 1.00 & 16.7 \\
\hline Halomonas sp. ${ }^{\mathrm{a}}$ & 19.3 & $\mathbf{0 . 0 0}$ & 27.1 & 24.2 & 0.00 & 0.00 & 28.5 & 0.00 & $\mathbf{0 . 0 0}$ & $\mathbf{0 . 8 0}$ & 16.7 \\
\hline \multicolumn{12}{|c|}{ Biavin 109 medium blue dye } \\
\hline Heavy metal $(\mathrm{mg} / \ell)^{\mathrm{c}}$ & $\begin{array}{c}\mathbf{A s}^{3+} \\
0\end{array}$ & $\begin{array}{l}\mathbf{C u}^{2+} \\
0.20\end{array}$ & $\begin{array}{l}\mathbf{P b}^{2+} \\
0.02\end{array}$ & $\begin{array}{c}\mathbf{M n}^{2+} \\
39.2\end{array}$ & $\begin{array}{l}\mathbf{N i}^{2+} \\
0.09\end{array}$ & $\begin{array}{l}\mathbf{A l}^{3+} \\
0.30\end{array}$ & $\begin{array}{l}\mathbf{Z n}^{2+} \\
1.21\end{array}$ & $\begin{array}{l}\mathbf{C r}^{2+} \\
0.15\end{array}$ & $\begin{array}{l}\mathbf{C d}^{2+} \\
0.96\end{array}$ & $\begin{array}{l}\mathbf{F e}^{2+} \\
3.01\end{array}$ & $\begin{array}{c}\mathbf{H g}^{2+} \\
0\end{array}$ \\
\hline Bioflocculant & \multicolumn{11}{|c|}{ Heavy metal removal (\%) } \\
\hline Herbaspirillium sp. & $\mathbf{0 . 0 0}$ & 27.9 & 25.0 & 71.1 & 89.2 & 22.1 & 8.00 & 94.9 & $\mathbf{0 . 0 0}$ & 65.3 & 0.00 \\
\hline Paenibacillus sp. ${ }^{\mathbf{b}}$ & $\mathbf{0 . 0 0}$ & 63.2 & 47.0 & 66.7 & 94.0 & 40.4 & 11.0 & $\mathbf{5 7 . 5}$ & $\mathbf{0 . 0 0}$ & 65.2 & 0.00 \\
\hline Bacillus sp..$^{\mathbf{a}, \mathbf{b}}$ & $\mathbf{0 . 0 0}$ & 68.0 & 87.0 & 73.1 & 74.3 & 54.7 & 16.1 & 86.4 & $\mathbf{0 . 0 0}$ & 64.6 & $\mathbf{0 . 0 0}$ \\
\hline Halomonas sp. ${ }^{\mathbf{a}, \mathbf{b}}$ & $\mathbf{0 . 0 0}$ & 60.3 & 75.0 & 86.3 & 65.5 & 41.7 & 13.3 & 69.3 & $\mathbf{0 . 0 0}$ & 6.90 & 0.00 \\
\hline \multicolumn{12}{|l|}{ Whale dye } \\
\hline Heavy metal $(\mathrm{mg} / \ell)^{\mathrm{c}}$ & $\begin{array}{c}\mathbf{A s}^{+3} \\
0 \\
\end{array}$ & $\begin{array}{c}\mathbf{C} \mathbf{u}^{+2} \\
0.18 \\
\end{array}$ & $\begin{array}{l}\mathbf{P b}^{+2} \\
0.38\end{array}$ & $\begin{array}{c}\mathbf{M n}^{+2} \\
35.0 \\
\end{array}$ & $\begin{array}{l}\mathbf{N i}^{+2} \\
5.81 \\
\end{array}$ & $\begin{array}{l}\mathbf{A l}^{+3} \\
0.39 \\
\end{array}$ & $\begin{array}{l}\mathbf{Z n}^{+2} \\
1.25 \\
\end{array}$ & $\begin{array}{l}\mathbf{C r}^{+2} \\
0.03 \\
\end{array}$ & $\begin{array}{l}\mathbf{C d}^{+2} \\
0.96\end{array}$ & $\begin{array}{l}\mathbf{F e}^{+2} \\
1.30 \\
\end{array}$ & $\begin{array}{c}\mathbf{H g}^{+2} \\
0 \\
\end{array}$ \\
\hline Bioflocculant & \multicolumn{11}{|c|}{ Heavy metal removal (\%) } \\
\hline Herbaspirillium sp. & $\mathbf{0 . 0 0}$ & 13.1 & 5.50 & 16.0 & 17.4 & $\mathbf{1 1 . 5}$ & 16.8 & 54.9 & $\mathbf{0 . 0 0}$ & 11.2 & 0.00 \\
\hline Paenibacillus sp. ${ }^{\mathbf{b}}$ & $\mathbf{0 . 0 0}$ & 13.9 & 7.00 & 21,8 & 18.1 & 11.6 & 17.2 & 54.0 & 0.00 & 11.6 & 0.00 \\
\hline Bacillus sp. ${ }^{\mathbf{b}}$ & $\mathbf{0 . 0 0}$ & 11.7 & 6.30 & 16.2 & 15.3 & 6.60 & 17.3 & 55.9 & 0.00 & 10.0 & 0.00 \\
\hline Halomonas sp. ${ }^{\mathbf{b}}$ & $\mathbf{0 . 0 0}$ & 10.5 & 6.50 & 11.9 & 16.1 & 7.50 & 15.7 & 46.1 & 0.00 & 6.70 & 0.00 \\
\hline
\end{tabular}

a, $b$ : Test values for the same bioflocculant carrying the same superscripts for different effluent samples are significantly different $(P<0.05)$.

${ }^{c}$ The heavy metal concentrations detected in the control samples 
reported for the chemical-industry effluents. The concentrations of metals in the textile-industry effluents were much lower than those from the chemical-industry effluent. No $\mathrm{As}^{2+}$ or $\mathrm{Hg}^{2+}$ was detected in the textile-industry samples. However, higher $\mathrm{Mn}^{2+}$ concentrations ( 35.0 and $39.2 \mathrm{mg} / \ell$ ) were present in both textile-industry effluents than in the chemicalindustry effluent $(10.2 \mathrm{mg} / \ell)$. Both textile effluents contained $1 \mathrm{mg} / \ell$ of $\mathrm{Cd}^{2+}$ and the Whale dye effluent contained $5.81 \mathrm{mg} / \ell$ of $\mathrm{Ni}^{2+}$; concentrations of $\mathrm{Cd}^{2+}$ and $\mathrm{Ni}^{2+}$ were higher in the textile-industry effluents than in the chemical-industry effluents.

None of the bacterial bioflocculants (1 000 $\mathrm{mg} / \ell$ ) was capable of removing $\mathrm{Cd}^{2+}$ from any of the effluent samples (Table 1). The efficiency of each bacterial bioflocculant in removing different heavy metals from the industrial effluents varied. The efficiency of all bioflocculants in removing $\mathrm{Mn}^{2+}$ from the Biavin blue dye effluent and from the Whale dye effluent was in the range of $67-86 \%$ and $12-22 \%$, respectively, while the concentrations of $\mathrm{Mn}^{2+}$ in both effluents were very similar (Table 1). Similar observations were noted regarding the abilities of these bioflocculants in removing $\mathrm{Ni}^{2+}$ from Biavin blue dye and Whale dye effluents, being in the range of $66-94 \%$ and $15-18 \%$, respectively.

Bioflocculants produced in this study were able to remove several heavy metals simultaneously. Despite the relatively low concentrations of heavy metals in the Biavin blue dye and Whale dye effluents, bioflocculant produced by Herbaspirillium sp. $\mathrm{CH} 7$ removed $\mathrm{Cr}^{2+}(95 \%), \mathrm{Ni}^{2+}(89 \%), \mathrm{Mn}^{2+}(71 \%), \mathrm{Fe}^{2+}$ $(63 \%)$ and other heavy metals effectively from the Biavin blue dye effluent. Bioflocculant produced by Bacillus sp. CH15 was capable of removing $\mathrm{Pb}^{2+}(87 \%)$ and $\mathrm{Cr}^{2+}(86 \%)$ more effectively compared to other heavy metals from the same effluent (Table 1). In general, the efficiency of bacterial bioflocculants in removing heavy metals from the Whale dye effluent was significantly lower $(p<0.05)$ from the Whale dye effluent than the Biavin blue dye effluent. The efficiency of bacterial bioflocculants in removing heavy metals was also lower for the chemical effluent than the Biavin blue dye effluent, but not significantly so $(p>0.05)$. It is also important to mention that bioflocculants were able to remove $17-33 \%$ of $\mathrm{Hg}^{2+}$ even though the concentration of $\mathrm{Hg}^{2+}$ was only $0.6 \mathrm{mg} / \ell$ and $\mathrm{As}^{2+}$ and $\mathrm{Zn}^{2+}$ concentrations were high in the same effluent (Table 1). Heavy-metal removal percentages by bioflocculants produced by Bacillus sp. and Halomoas sp. were significantly lower $(p<0.05)$ for the chemical-industry effluent than for the Biavin blue dye effluent, but not the Whale dye effluent. Significant increases were also found in the heavy-metal removal percentages, for all bioflocculants, from the Biavin blue dye effluent compared to the Whale dye effluent,.

Table 2 shows the bacterial population in the industrial effluent samples with and without treatment with $1000 \mathrm{mg} / \ell$ of bioflocculant. A highly populated bacterial community was present in the chemical-industry effluent compared to the other 2 samples (Table 2). All bacterial bioflocculants in this study possessed the ability to flocculate almost $100 \%$ of bacteria present in the chemical effluent. Though all bacterial bioflocculants in this study were able to remove bacteria from the Biavin blue dye and Whale dye effluents, this was with significantly lower efficiency. The study further showed that bioflocculants
Table 2

Heterotrophic plate count (cfu per me) of industrial effluent samples before and after the treatment with $1000 \mathrm{mg} / \mathrm{l}$ bioflocculant from 4 bacterial species

c|l|l|lor

\begin{tabular}{l|l|l|}
$10^{-2}$ & $10^{-4}$ & $10^{-6}$ \\
\hline
\end{tabular}

\begin{tabular}{|c|c|c|c|c|}
\hline \multicolumn{5}{|c|}{ Chemical-industry effluent } \\
\hline Control & TNTC & TNTC & TNTC & TNTC \\
\hline Herbaspirillium sp. & 81 & 0 & 0 & 0 \\
\hline Paenibacillus sp. & 92 & $2 \times 10^{3}$ & 0 & 0 \\
\hline Bacillus sp. & 88 & 0 & 0 & 0 \\
\hline Halomonas sp. & 82 & 0 & 0 & 0 \\
\hline \multicolumn{5}{|c|}{ Biavin 109 medium blue dye } \\
\hline Control & TNTC & TNTC & $2.80 \times 10^{5}$ & $5 \times 10^{5}$ \\
\hline Herbaspirillium sp. & TNTC & TNTC & $2.57 \times 10^{5}$ & $2 \times 10^{5}$ \\
\hline Paenibacillus sp. & TNTC & TNTC & $4.1 \times 10^{4}$ & 0 \\
\hline Bacillus sp. & TNTC & TNTC & $3.2 \times 10^{4}$ & $1 \times 10^{5}$ \\
\hline Halomonas sp. & TNTC & TNTC & $2 \times 10^{3}$ & 0 \\
\hline \multicolumn{5}{|l|}{ Whale dye } \\
\hline Control & TNTC & TNTC & $7.8 \times 10^{4}$ & $2 \times 10^{5}$ \\
\hline Herbaspirillium sp. & TNTC & $2.04 \times 10^{3}$ & $3.9 \times 10^{4}$ & 0 \\
\hline Paenibacillus sp. & TNTC & $2.02 \times 10^{3}$ & $4.2 \times 10^{4}$ & 0 \\
\hline Bacillus sp. & TNTC & $2.49 \times 10^{3}$ & $2.8 \times 10^{4}$ & 0 \\
\hline Halomonas sp. & TNTC & $2.47 \times 10^{3}$ & $9 \times 10^{3}$ & 0 \\
\hline
\end{tabular}

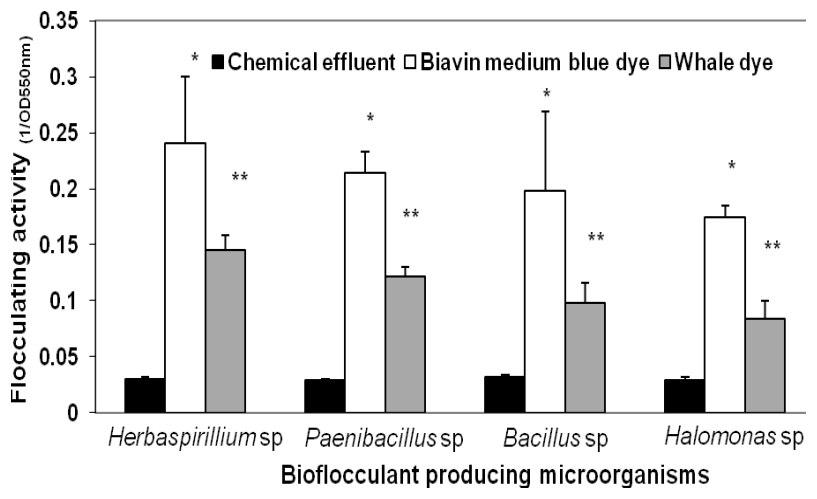

Figure 1

Flocculating activity of bacterial bioflocculants applied to various industrial effluents. All results were present as the means + $S D(n=3) .{ }^{* * *}:$ Test values for the same bioflocculant carrying superscripts are significantly different $(P<0.05)$ when compared to the results for the other effluents.

that possessed better abilities in removing heavy metals from the Biavin blue dye effluent, as shown in Table 1, demonstrated a better flocculating activity (Fig. 1), but had lower capacity in binding the bacteria (Table 2). On the other hand, bacterial bioflocculants which had lower flocculating activities and lower capacity in removing heavy metals, could remove almost $100 \%$ of the bacterial population from the chemical industrial effluent. The flocculating activity of bioflocculant produced by Herbaspirillium sp. $\mathrm{CH} 7$ was 0.24 in the Biavin blue dye effluent compared to 0.028 in the chemical-industry effluent. The flocculating activities of bioflocculants were statistically different $(p<0.05)$ when applied to different industrial effluents (Fig. 1).

All bioflocculants were capable of decreasing the turbidity of the selected industrial effluent samples (Fig. 2). Bioflocculants produced by Herbaspirillium sp. $\mathrm{CH} 7$ decreased the turbidity of the chemical industrial effluent sample by $82 \%$ 


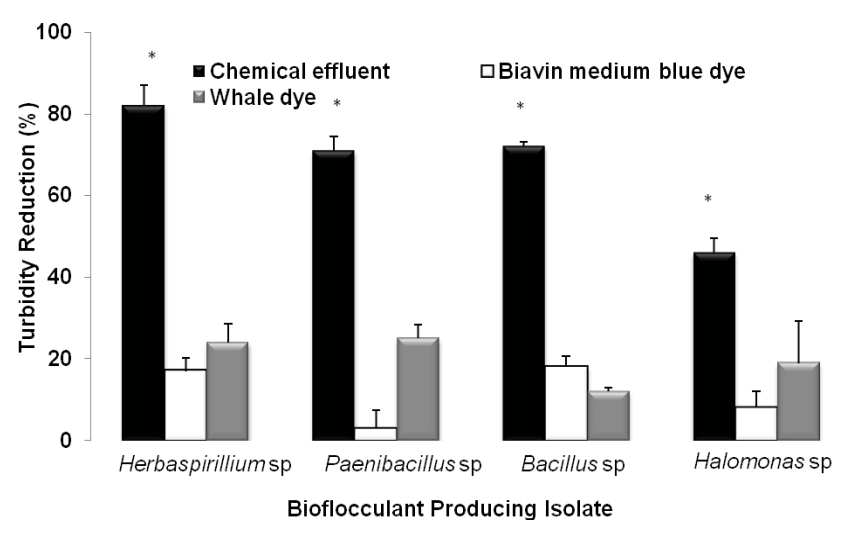

Figure 2

Percentage of turbidity reduction of industrial effluent samples 5 min after flocculating with bioflocculants. All results are presented as means $+S D(n=3)$. * Test values for the same bioflocculant carrying superscripts are significantly different $(P<0.05)$ when compared to results for the other effluents.

compared to the less than $25 \%$ reduction in the textile effluents Significant differences in the turbidity reductions by bioflocculants for the chemical-industry effluent sample versus the other 2 effluents were observed ( $p<0.05)$, but there was no significant difference between the turbidity reductions for the 2 dye effluent samples $(p>0.05)$. A negative correlation $(r=-0.831$; $p<0.05$ ) between the flocculating activity of bioflocculant (Fig. 1) and the percentage of turbidity reduction (Fig. 2) was also observed.

\section{Discussion}

In wastewater treatment, bioflocculants have been used to treat dye solutions (Deng et al., 2005; Gao et al., 2009; Liu et al., 2009), inorganic solid suspensions (Natarajan and Das, 2003; Lu et al., 2005; Yim et al., 2007), humic acids (Zouboulis et al., 2004) and others (Deng et al., 2003; Vijayalakshmi and Raichur, 2003; Lu et al., 2005; Aguilera et al., 2008). However, knowledge on the treatment of real wastewaters is lacking or scarce (Deng et al., 2003). Gong et al. (2008) demonstrated that bioflocculants produced by Serratia ficaria were able to remove the colour and chemical oxygen demand (COD) of pulp effluent more effectively than traditional chemical flocculants.

Most wastewaters, especially industrial effluents, contain various types of chemicals and different kinds of heavy metals, as demonstrated in this study. At present, metal-polluted industrial effluents are mainly treated using chemical methods. These methods are less effective and are costly to implement when the metal concentration is low (Volesky, 1990). In addition, these methods are task-specific. Bioflocculants produced by microorganisms are capable of flocculating heavy metals and microorganisms as well as decolourising dye solutions (Nakata and Kurane, 1999; Gao et al., 2009).

The high concentrations of $\mathrm{As}^{2+}(284 \mathrm{mg} / \ell)$ and $\mathrm{Zn}^{2+}(252$ $\mathrm{mg} / \ell$ ) in the chemical-industry effluents (Table 1) could be a serious concern if a large quantity of this effluent was released into the environment on a regular basis without proper treatment. Arsenic and zinc are ranked $1^{\text {st }}$ and $74^{\text {th }}$ among the heavy metals in terms of toxicity (Srivastava and Majumder, 2008). According to the Comprehensive Environmental Response, Compensation and Liability Act (CERCLA) of the United States Environmental Protection Agency, the maximum concentration limits of $\mathrm{As}^{+3}$ and $\mathrm{Zn}^{+2}$ are $0.01 \mathrm{mg} / \ell$ and $5.0 \mathrm{mg} / \ell$, respectively. Concentrations of several other metals, such as $\mathrm{Hg}^{+2}(0.6 \mathrm{mg} / \ell), \mathrm{Cd}^{+2}$ and $\mathrm{Mn}^{+2}$ found in the chemical-industry effluent, as well as $\mathrm{Cd}^{+2}$ and $\mathrm{Mn}^{+2}$ in the textile effluents, were also higher than the limits set by CERCLA.

This study has demonstrated the ability of these bioflocculants to remove heavy metals (Table 1) and the bacterial population (Table 2), indicating multiple functions of these bioflocculants. It is, however, not clear whether metals were removed separately or adsorbed to biomass which was then flocculated out. It seems that most flocculants were able to completely remove bacteria from the chemical-industry effluent but not the dye effluents, implying that the flocculation might be effluentdependent rather than microbial-loading dependent. The presence of more than 1 metal and other (microbial and suspended solid) contaminants in effluents may have an impact on the properties of the bioflocculant, as demonstrated in our results. The bioflocculants used in this study possessed the ability to remove up to $90 \%$ of $\mathrm{Cd}^{2+}$ from a $1 \mathrm{mg} / \ell \mathrm{Cd}^{2+}$ solution (Lin and Harichund, unpubl. results), but failed to bind to the same metal in all effluent treatments (Table 1). The impact of the presence of the microbial population and other suspended solids on the heavy-metal removal capacity of the bioflocculant is unknown. It is also possible that high concentrations of $\mathrm{As}^{3+}$ and $\mathrm{Zn}^{2+}$ have an impact on the poor binding of other heavy metals to bioflocculants in the chemical effluent. The efficiency of bioflocculant in removing heavy metals is dependent on heavy metal and bioflocculant concentration (Salehizadeh and Shojaosadati, 2003; Lin and Harichund, unpubl. results). In addition, each bioflocculant possesses its own heavy metal binding specificity (Micheletti et al., 2008). Specific heavy metal uptake by bioflocculants can also be inhibited in the presence of other metal ions. The inhibition of metal removal ability of each bioflocculant by other particles might be a result of an interference effect (Salehizadeh and Shojaosadati, 2003).

Flocculation of bacterial cells and a reduction in turbidity during effluent treatments by bioflocculants was also observed in this study (Table 2; Fig. 2). A considerable reduction in the number of bacterial cells and in turbidity in the chemical effluent was evident. Nakata and Kurane (1999) have reported on the flocculating ability of bacterial cells. The flocculation of bacterial cells using bacterial bioflocculants has not gained much attention, since water purification techniques such as chlorination are effective for removal of bacteria during wastewater treatment processes. At the same time, our results show that there is a negative correlation $(r=-0.831)$ between the flocculating activities of bioflocculants and the percentage turbidity reduction achieved. The flocculating activity of bioflocculants produced in this study decreases with the presence of $\mathrm{Pb}^{2+}$ and $\mathrm{Zn}^{2+}$ (Lin and Harichund, unpubl. results), when compared to the presence of $\mathrm{Ca}^{+2}$ in the standard flocculating assay. High heavy metal concentrations $\left(\mathrm{As}^{+3}\right.$ and $\left.\mathrm{Zn}^{+2}\right)$ in the chemicalindustry effluent might have an impact on the turbidity reduction in the effluent even though the bioflocculants have good flocculating activity.

Tables 1 and 2 and Figs. 1 and 2 clearly demonstrate the benefits of using bioflocculants in the treatment of wastewater and industrial effluents. Microbial flocculants were capable of removing several heavy metals, suspended solids and microbial contaminants effectively and simultaneously from these effluents, as demonstrated by other researchers (Nakata and Kurane, 1999; Gao et al., 2009). Our results demonstrate that bioflocculant produced by Herbaspirillium sp. $\mathrm{CH} 7$ possesses the ability to flocculate several heavy metals, suspended solids and microorganisms, and to reduce the turbidity of industrial 
effluents. However, the efficiency of each activity of bacterial bioflocculant varies depending on the effluent sample. Gong et al. (2008) also demonstrated the decolourising and heavy metal removal abilities, for a dye effluent, of bioflocculant produced by Serratia ficaria. They further showed that the use of bioflocculants in the treatment of effluent can be more effective than traditional chemical flocculants. The concentrations of heavy metals present in the textile effluent samples were low. Removal of metals from any water source at low concentrations is expensive using conventional techniques (Volesky, 1990). To be able to effectively remove several classes of contaminants from wastewater or industrial effluents in one simple treatment by using bacterial bioflocculants should provide some economical and operational benefits in addition to the environmental safety considerations. A combination of bioflocculation and other techniques can be implemented if beneficial in the treatment of industrial effluents.

These above findings also illustrate that wastewater and effluent treatment using bioflocculants in the 'real case' may be very complicated. The composition of the individual effluents may vary within different processes and within each occurrence. The use of the bioflocculants obtained in this study in the treatment of industrial effluents still requires experimentation to determine the optimal concentration for each effluent, as well as the cost, and to understand the modes of bioflocculant activity.

\section{Conclusion}

This preliminary study has shown that bacterial bioflocculants are capable of simultaneously removing several heavy metals, bacterial cells and suspended solids from industrial effluents. The alternative use of microbe-based bioflocculants, or combination with other techniques, for industrial effluent treatment may be economically and environmentally beneficial. Our findings, however, suggest that the behaviour of bioflocculants may be effluent-dependent and effluent treatments using bioflocculants in the 'real case' may be very complicated. Therefore more studies are needed to understand the modes of flocculation activities by bioflocculants. Optimal efficiency using bioflocculants in industrial applications requires further investigation.

\section{Acknowledgement}

This research was funded by the National Research Foundation (NRF) of South Africa. The second author is grateful to the NRF for the award of a Masters bursary. The authors would also like to express their sincere gratitude toward Prof T Puckree, Executive Dean (Health Science) at the Durban University of Technology for editing the manuscript.

\section{References}

AGUILERA M, QUESADA MT, AGUILA VGD, MORILLO JA, RIVADENEYRA MA, CORMENZANA AR and SANCHEZ MM (2008) Characterization of Paenibacillus jamilae strains that produce exopolysaccharide during growth on and detoxification of olive mill wastewaters. Bioresour. Technol. 99 5640-5644.

BENDER J, RODRIGUEZ-EATON S, EKANEMESANG UM and PHILLIPS P (1994) Characterization of metal-binding bioflocculants produced by the cyanobacterial component of mixed microbial mats. Appl. Environ. Microbiol. 60 (7) 2311-2315.

CHISTI Y (2004) Environmental impact of toxic pollutants. Biotech. Adv. 6 431-432.
DENG SB, BAI RB, HU XM and LUO Q (2003) Characteristics of a bioflocculant produced by Bacillus mucilaginosus and its use in starch wastewater treatment. Appl. Microbiol. Biotechnol. 60 588-593.

DENG SB, YU G and TING YP (2005) Production of a bioflocculant by Aspergillus parasiticus and its application in dye removal. Colloids Surf. B: Biointerfaces 44 179-186.

DIGNAC MF, URBAIN V, RYBACKI D, BRUCHET A, SNIDARO D and SCRIBE P (1998) Chemical description of extracellular polymers: implication on activated sludge floc structure. Water Sci. Technol. 38 (3) 9-46.

EL-SHEEKH MM, EL-SHOUNY WA, OSMAN MEH and EL-GAMMAL EWE (2005) Growth and heavy metals removal efficiency of Nostoc muscorum and Anabaena subcylindrica in sewage and industrial wastewater effluents. Environ. Toxicol. Pharmacol. 19 (2) 357-365.

GAO Q, ZHU X-H, MU J, ZHANG Y and DONG X-W (2009) Using Ruditapes philippinarum conglutination mud to produce bioflocculant and its applications in wastewater treatment. Bioresour. Technol. 100 4996-5001.

GONG W-X, WANG S-G, SUN X-F, LIU X-W, YUE Q-Y and GAO B-Y (2008) Bioflocculant production by culture of Serratia ficaria and its application in wastewater treatment. Bioresour. Technol. 99 4668-4674.

GUANGYU Y and THIRUVENKATACHARI V (2003) Heavy metals removal from aqueous solution by fungus Mucor rouxii. Water Res. 37 (18) 4486-4496.

HEREDIA JB and MARTÍN JS (2009) Removing heavy metals from polluted surface water with a tannin-based flocculant agent. $J$. Hazardous Mater. 165 1215-1218.

KOZUL CD, ELY KH, ENELOW RI and HAMILTON JW (2009) Low-dose arsenic compromises the immune response to Influenza A infection in vivo. Environ. Health Perspect. 117 (9) 1441-1447.

KURANE R, HATAMOCHI K, KAKUNO T, KIYOHARA M, KAWAGUCHI K, MIZONO Y, HIRANO M and TANIGUCHI Y (1994) Production of a bioflocculant by Rhodococcus ertythropolis S-1 grown on alcohols. Biosci. Biotechnol. Biochem. 58 428-429.

LI Z, ZHONG S, LEI H-Y, CHEN R-W, YU Q and LI H-L (2009) Production of a novel bioflocculant by Bacillus licheniformis X14 and its application to low temperature drinking water treatment. Bioresour. Technol. 100 3650-3656.

LIU W-J, YUAN H-L, YANG J-S and LI B-Z (2009) Characterization of bioflocculants from biologically aerated filter backwashed sludge and its application in dying wastewater treatment. Bioresour. Technol. 100 2629-2632.

LU WY, ZHANG T, ZHANG DY, LI CH, WEN JP and DU LX (2005) A novel bioflocculant produced by Enterobacter aerogenes and its use in defecating the trona suspension. Biochem. Eng. J. 27 1-7.

MICHELETTI E, COLICA G, VITI C, TAMAGNINI P and PHILIPPIS RD (2008) Selectivity in the heavy metal removal by exopolysaccharide-producing cyanobacteria. J. Appl. Microbiol. $10588-94$.

NAKATA K and KURANE R (1999) Production of an Extracellular Polysaccaride Bioflocculant by Klebsiella pneumoniae. Biosci. Biotechnol. Biochem. 63 2064-2068.

NATARAJAN KA and DAS A (2003) Surface chemical studies on 'Acidithiobacillus' group of bacteria with reference to mineral flocculation. Int. J. Miner. Process. 72 189-198.

REHMAN A, SHAKOORI FR and SHAKOORI AR (2008) Heavy metal resistant freshwater ciliate, Euplotes mutabilis, isolated from industrial effluents has potential to decontaminate wastewater of toxic metals. Bioresour. Technol. 99 3890-3895.

SALEHIZADEH H and SHOJAOSADATI SA (2003) Removal of metal ions from aqueous solution by polysaccharide produced from Bacillus firmus. Water Res. 37 4231-4235.

SHIH IL, VAN YT, YEH LC, LIN HG and CHANG YN (2001) Production of a biopolymer flocculant from Bacillus licheniformis and its flocculation properties. Bioresour. Technol. 78 267-272.

SRIVASTAVA NK and MAJUMDER CB (2008) Novel biofiltration methods for the treatment of heavy metals from industrial wastewater. J. Hazardous Mater. 151 1-8. 
VIJAYALAKSHMI SP and RAICHUR AM (2003) The utility of Bacillus subtilis as a bioflocculant for fine coal. Colloids Surfaces B 29 265-275.

VOLESKY B (1990) Biosorption of Heavy Metals. CRC Press, Boston, USA.

WANG S-G, GONG W-X, LIU X-W, TIAN L, YUE Q-Y and GAO B-Y (2007) Production of a novel bioflocculant by culture of Klebsiella mobilis using dairy wastewater. Biochem. Eng. J. 36 81-86.

WU JY and YE HF (2007) Characterization and flocculating properties of an extracellular biopolymer produced from a Bacillus subtilis DYU1 isolate. Process Biochem. 42 1114-1123.

YIM JH, KIM SJ, AHN SH and LEE HK (2007) Characterization of a novel bioflocculant p-KG03 from a marine dinoflagellate, Gyrodinium impudicum KG03. Bioresour. Technol. 98 361-367. ZHENG L, TIAN Y, DING A-Z and WANG J-S (2008) Adsorption of $\mathrm{Cd}(\mathrm{II}), \mathrm{Zn}(\mathrm{II})$ by extracellular polymeric substances extracted from waste activated sludge. Water Sci. Technol. 58 (1) 195-200. ZOUBOULIS AI, CHAI XL and KATSOYIANNIS I (2004) The application of bioflocculant for the removal of humic acids from stabilized landfill leachates. J. Environ. Manage. 70 35-41. 